\title{
高度血小板減少を伴った抗リン脂質抗体症候群患者における抜歯経験
}

\author{
来生知 ·堀本進 - 宮崎千佳 \\ 平田雅嗣・川辺良一・藤田浄秀
}

\section{Antiphospholipid antibody syndrome}

\section{- a patient with serious thrombocytopenia who underwent oral surgery -}

\author{
Mitomu Kior $\cdot$ Susumu Horimoto $\cdot$ Chika Miyazaki \\ Masatsugu Hirata $\cdot$ Ryoichi Kawabe $\cdot$ Kiyohide Fujita
}

\begin{abstract}
Antiphospholipid antibody syndrome (APS) is characterized by thrombocytopenia, habitual abortion, and arteriovenous thrombosis.

We report the case of a 32-year-old man with APS in whom an erupted maxillary third molar had to be extracted. The tooth was extracted while carefully monitoring hemostasis because of the presence of thrombocytopenia $\left(2.4 \times 10^{4} / \mu \ell\right)$. The wound healed without any local or systemic complications.

When patients with APS are referred to oral and maxillofacial surgeons, it is important to be aware of APS, especially with regard to the perioperative care of general arteriovenous thrombosis and oral hemostasis.
\end{abstract}

Key words: antiphospholipid antibody syndrome（抗リン脂質抗体症候群）, thrombocytopenia (血小板減少), lupus anticoagulant (ループス抗凝固因子), anticardiolipin antibody (抗カルジオリピン抗体), hemorrhagic diathesis (出血性素因)

緒

\section{言}

抗リン脂質抗体症候群 (Antiphospholipid Antibody Syndrome; 以下 APS）は, 動静脈血栓症 · 習 慣性流産・血小板減少等を伴う症候群で，1986年 Hughse ら 1)によって提唱された. 本症候群における 血小板減少は一般に軽度で, 臨床的に出血傾向を示す ものは少ないと考えられている ${ }^{2)}$ が, 口腔外科臨床に おける病態は, 報告も少なく, 明確にされているとは 言い難い。

今回われわれは高度血小板減少を伴った APS 患者に おける抜歯症例を経験したので，その概要を報告する.

横浜市立大学医学部口腔外科学講座

（主任 : 藤田浄秀教授）

Department of Oral and Maxillofacial Surgery, Yokohama City University School of Medicine (Chief: Prof. Kiyohide Fujita)

受付日: 平成 9 年10月 2 日
症

例

患 者: 38歳, 男性.

初 診: 1995年11月日日.

主 訴 : 右側上顎智歯部の疼痛.

現病歴 : 1995年11月 8 日より右側上顎智歯部の疼痛 を自覚したため近歯科を受診し, 智歯周囲炎の診断に て投薬を受け, 改善した. その後抜歯を予定したが血 小板減少症を合併していたため, 紹介により当科を初 診した。

既往歴 : 1994年より本院内科にて APS の診断をう けるが, 特に投薬などは行われず, 現在経過観察中で ある。

家族歴：特記事項はない.

現 症 : 全身所見として体格中等度で動静脈血栓症 を疑わせる所見は認めなかった. 局所所見としては右 側上顎智歯周囲の歯肉に軽度の発赤・腫脹を認めた (写真 1 ).

術前血液検查所見：血小板が $2.4 \times 10^{4} / \mu \ell$ と高度 


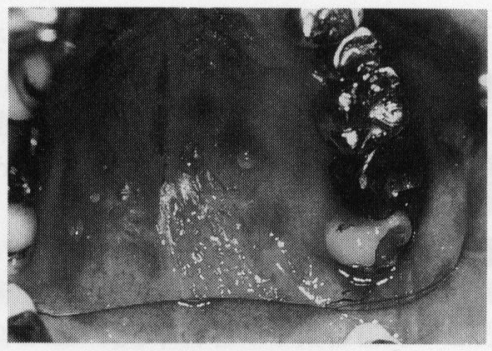

写真 1 術前口腔内写真 (ミラー使用) 右側上顎智歯周囲の歯肉に軽度の発赤. 腫脹を認めた。 また口蓋右側に毛細血 管の拡張を認めた.

表 1 初診時血液検查所見

\begin{tabular}{ll}
\hline WBC & $4100 / \mu \ell$ \\
$\mathrm{RBC}$ & $451 \times 10^{4} / \mu \ell$ \\
$\mathrm{Hb}$ & $15.3 \mathrm{~g} / \mathrm{d} \ell$ \\
$\mathrm{Ht}$ & $44.2 \%$ \\
$\mathrm{PLT}$ & $2.4 \times 10^{4} / \mu \ell$ \\
$\mathrm{PT}(\mathrm{INR})$ & $1.07 \mathrm{INR}$ \\
$\mathrm{APTT}$ & $53.8 \mathrm{sec}$ \\
抗カルジオリピン IgG 抗体 & 1.6 (正常值1.0 >) \\
(ELISA 法) & \\
梅毒血清学的検查 & \\
$\quad$ 凝集法 & \\
$\quad$ ガラス板法 & 陽性 \\
TRHA 法 & 陽性 \\
\hline
\end{tabular}

の滅少を呈しており, APTT は53.8秒と延長していた. また血清梅毒反応の生物学的偽陽性がみられた。さら に $\mathrm{IgG}$ 型抗カルジオリピン抗体も陽性であった。 その 他血液検査に異常所見は認められなかった（表 1 ).

\section{処置および経過}

1996年 1 月—，8万倍希釈エピネフリン添加 $2.0 \%$ リドカインにて浸潤麻酔を行い, 右側上顎智歯の抜歯 を行った. 抜歯は通法にしたがって行い,この際止血 目的として抜歯窩にアテロコラーゲンスポンジを挿入 し(写真 2 ), さらに止血シーネにて圧迫固定を行った. 抜歯後の異常出血は認めなかったが, 抜歯当日は後出 血に対処しうるよう入院とした. 後出血は認められず 翌日には退院し, 抜歯後 5 日目に外来にて止血シーネ を除去した. その後, 出血・歯肉潰瘍など異常所見は 認められず，良好な治癒を得た. 全身的にも異常所見 は認めなかった。

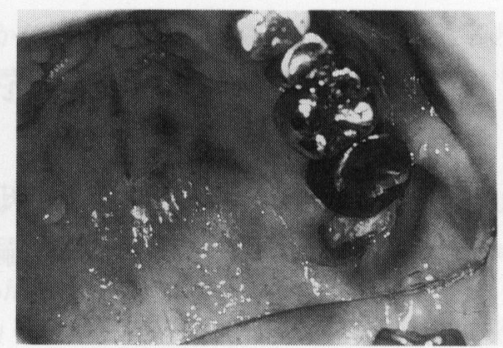

写真 2 抜歯後口腔内写真 (ミラー使用) 止血目的として抜歯窩にアテロコラー ゲンスポンジを挿入した。

表 2 APS の診断基準 (Harris ら, 1987)

\begin{tabular}{|c|c|}
\hline 1. 臨床所見 & $\begin{array}{l}\text { 動静脈血栓症 } \\
\text { 習慣性流産 } \\
\text { 血小板減少 }\end{array}$ \\
\hline 2. 血清学的検査 & $\begin{array}{l}\text { 抗カルジオリピン抗体 IgM 陽性 } \\
\text { 抗カルジオリピン抗体 IgG 陽性 } \\
\text { ループス抗凝固因子陽性 }\end{array}$ \\
\hline
\end{tabular}

1,2 でそれぞれ少なくとも 1 つ以上有するもの

\section{考察}

APS は, 抗カルジオリピン抗体やループス抗凝固 因子などの抗リン脂質抗体によって, 動静脈血栓・習 慣性流産・血小板減少などの臨床症状を呈する比較的 新しい概念の症候群 ${ }^{1}$ ) である. 抗リン脂質抗体は従来, 身体構成成分であるリン脂質に対する抗体であると考 えられてきたが, 近年, その中に直接リン脂質に反応 する抗体とリン脂質と結合した血清中の $\beta_{2}$-glycoprotein Iなどのアポリポ蛋白やプロトロンビンなど に対する抗体とが存在することを示唆する報告もあり， 真の抗原に対しては未だ一致した見解はない 3 ).

APS における動静脈血栓症の血栓形成過程は, 詳 細が不明であるが, 臨床的には多様性で再発性を示し, 大血管よりもむしろ中小の血管に好発する. 四肢血栓 性静脈炎や一過性脳虚血発作・多発性脳梗塞などが見 られる。

女性では習慣性流産は APSにおける最も重要な臨 床症状とも言え, 不育症全体の約 $10 ２ 0 \%$ を占めると の報告もある ${ }^{5}$.

血小板減少に関しては抗リン脂質抗体の血小板膜上 リン脂質への結合による血小板破壇や, 血栓形成に伴 う血小板浪費などが原因として考えられているが，未 だ明らかではない2，4).しかし，いずれにしても臨床 的には軽度で，一般に出血傾向をきたすことは少ない 
と言われている2 .

APS の診断基準は, 1987年 Harris らによる基準が 広く用いられている6) (表 2 ). 本症例では, IgG 型抗 カルジオリピン抗体が 1.6 と正常値 1.0 以下に比べ高值 であり，陽性を示したささらに患者血清中に出現する 抗カルジオリピン抗体を反映していることが知られて いる血清梅毒反応の生物学的疑陽性 ${ }^{7}$ ) もみられた。

次に, ループス抗凝固因子の存在を示唆するとされ ている APTTの延長が本症例においても認めた。こ れは, 凝固系のカスケードの中で第 X 因子, 第 V 因子, $\mathrm{Ca}$, リン脂質からなるいわゆる prothrombin activator complexにループス抗凝固因子が作用して起こ るとされている8). しかし, APTT の延長は凝固因子 の欠損などでも見られるので, 被検者血獎と正常人血 漿の混合試験を行い，これによっても APTT が正常 化しないことでループス抗凝固因子の存在が確認され $ろ^{8)}$. したがって, 本症例においては APTT の延長を 認めるものの混合試験を施行していないため, ループ ス抗凝固因子陽性とは断定できない。しかしながら， 血小板の減少を認めたこと, 抗カルジオリピン抗体陽 性であることより本症例は APS と診断された.

APS 患者における口腔外科領域の外科的手術の際 に考えられる問題点として挙げられるのは，まず血小 板減少による出血傾向である. 本症候群における血小 板隇少は前述のごとく出血傾向を示すことは少ないと 考えられているが, Bernstein $5^{9)}$ の報告例など, 出 血傾向を示す症例も報告されている. 本症例でも術前 に高度な血小板減少を呈しており, 止血困難が予想さ れたが局所処置のみで抜歯後の異常出血はなく抜歯創 の治癒も良好であった。しかし，場合によっては一時

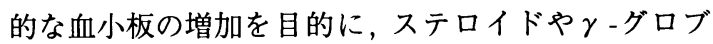
リンの大量投与 4 ), さらには血小板輸血も検討すべき であろう。

次に周術期管理上の問題として, 動静脈血栓症に対 する十分な配慮が必要である. 表在性の血栓による皮 膚潰湯・壊死はもちろんのこと, 静脈系では下肢の深 部静脈の血栓により肺動脈血栓・塞栓症や肺高血圧症 にいたる可能性が考えられ，また動脈系では脳梗塞・ 心筋梗塞などが挙げられる ${ }^{4)}$. さらに, APS の口腔領 域における症状として, 血栓に由来する合併症の報告 は現在のところなされていないが, 末梢動脈閉塞によ る口腔粘膜潰瘍などの可能性が推測される.

以上より，口腔外科的処置に際しては，血栓による 合併症を第一に考慮し, 全身的な止血剂投与よりも局 所的止血を優先すべきであろう.

APS が提唱されたのは 1986 年と比較的新しく, 口腔 外科領域での報告はわれわれの渉猟し得た限りでは 2 例のみ10,11)であった.しかし, SLEの20～80\%に抗り
ン脂質抗体陽性を認めるともいわれ 12 )，口腔外科臨床 においても遭遇するか可能性が十分にあり, 今後さらに 本症候群に対する認識を深める必要があると思われた.

$$
\text { ま と め }
$$

高度な血小板隇少を伴った APS 患者の抜歯を行い， 以下の結論を得た。

1. APS 患者に対する口腔外科的処置においては, 全身的な血栓による合併症を考慮しながら，局所的に 厳重な止血処置を行うべきであると思われた。

2. 今後本症候群に対して，十分に認識を深める必 要があると思われた.

本論文の要旨は, 第161回日本口腔外科学会関東地方会 （1996年, 埼玉）において発表した.

\section{引用文献}

1) Hughes, G.R.V., Harris, N.H., et al.: The anticardiolipin syndrome. J Rheumatol 13: 486-489 1986.

2) 戸田房子, 吉野谷定美 : 臨床検査, Modern Physician 15: 1573-1576 1995.

3) Roubey, R.A.S: Autoantibodies to phospholipidbinding plasma proteins. A new view of lupus anticoagulants and other "anti phospholipid" autoantibodies. Blood 84: 2854-2867 1994.

4) 三好義範, 堤 明人, 他 : 抗リン脂質抗体症候 群. 血液・腫瘍科 32: 27-31 1996.

5）高桑好一, 田中憲一：習慣流産（子宮内胎児死 亡). Modern Physician 15: 1585-1588 1995.

6) Harris, E.N: Antiphospholipid antibodies. Br J Haematol 74: 1 - 91990.

7）市川幸延, 保科裕一, 他 : 抗カルジオリピン抗 体検出法. Modern Physician 15:1551-1554 1995.

8）佐々木毅 : 免疫血清. Lab Clin Pract 12: 97-99 1994.

9) Bernstein, M.L., Salusinsky-Sternbach, M. et al.: Thrombotic and hemorrhagic complications in children with the lupus anticoaulant. AJDC 138: 1132-1135 1984.

10）高木 潤, 楽木正実, 他 : 抗リン脂質抗体症候 群 (APS) が原因と考えられる脳梗塞患者の歯 科治療経験. 日歯麻誌 25: 197-201 1997.

11）宮城島俊雄, 伊藤正樹, 他 : 抜歯前の検査で判 明した Lupus Anticoagulantを有する患者。 有病者歯科医療 $3: 17-201994$.

12）菊地正俊 : 膠原病患者における抗リン脂質抗体 の検討. 日臨免誌 15: 29-37 1992. 